\title{
Studi Fermentasi Biji Kopi Menggunakan Enzim Proteolitik
}

\author{
Imam Budiman ${ }^{1}$, Farizky Wahyudi ${ }^{2}$, Yunardi $^{3}$, Hesti Meilina ${ }^{4 *}$ \\ 1,2,3,4 Jurusan Teknik Kimia, Fakultas Teknik, Universitas Syiah Kuala \\ *Koresponden email: hesti.meilina@ che.unsyiah.ac.id
}

Diterima : 24 Agustus 2021

Disetujui: 7 September 2021

\begin{abstract}
Wet fermentation by added proteolytic enzyme can be used for upgrade the taste of coffee. The enzyme was obtained from plant because of ease to get and fulfill the term of Indonesia's constitution about halal product assurance. This study used two types of proteolytic enzyme; bromelain and zingibain that originated from pineapple and ginger, respectively. Coffee beans were fermented with weight ratio 1:4 and 3:4 (enzyme's source: coffee beans), and compared with a non-adding control and commercial coffee. Samples were collected after 1, 2 and 3 days. Roasted beans were physical and chemical evaluated according to Indonesia National Standard (SNI-01-3542-2004). Also, the sensorial evaluation of the roasted coffee beans was determined by organoleptic test. Physical and chemical evaluation consist of water content, ash content, coffee extract, ash alkalinity and caffeine content. Sensorial evaluation includes color, aroma and flavor.
\end{abstract}

Keywords: coffee, fermentation, proteolitict enzyme, bromelain, zingibain

\begin{abstract}
Abstrak
Fermentasi basah dengan penambahan enzim proteolitik dapat dimanfaatkan untuk meningkatkan cita rasa kopi. Enzim yang digunakan berasal dari tumbuhan karena kemudahannya untuk diperoleh dan memenuhi undang-undang Indonesia terkait jaminan produk halal. Studi ini menggunakan dua jenis enzim proteolitik yaitu bromelin dan zingibain yang berturut -turut berasal dari buah nanas dan jahe. Biji kopi difermentasi dengan rasio berat 1:4 dan 3:4 (sumber enzim banding kopi),dan akan dibandingkan dengan kopi kontrol, yang difermentasikan tanpa penambahan enzim, dan kopi komersial. Fermentasi biji kopi dilakukan selama 1,2, dan 3 hari. Biji kopi yang telah di-roasting akan diuji fisika dan kimia berdasarkan SNI-01-3542-2004. Uji organoleptik terhadap biji yang telah di-roasting juga dilakukan dengan organoleptik. Uji fisika dan kimia kopi terdiri dari kadar air, kadar abu, sari kopi, kealkalian abu dan kadar kafein. Uji organoleptik yang dilakukan meliputi warna, aroma dan rasa.
\end{abstract}

Kata Kunci : kopi, fermentasi, enzim proteolitik, bromelin, zingibain

\section{Pendahuluan}

Salah satu upaya yang dilakukan untuk meningkatkan cita rasa kopi adalah dengan mengatur tingkat kepahitan yang tepat. Hal ini diperlukan karena tingkat kepahitan kopi merupakan faktor utama dalam penerimaan konsumen. Salah satu treatment yang dilakukan untuk memperbaiki cita rasa kopi adalah melalui metode fermentasi basah (wet fermentation) menggunakan enzim [1]. Umumnya fermentasi basah digunakan untuk mengolah biji kopi Arabika. Alasannya, biji kopi Arabika dihargai lebih tinggi sehingga biaya operasional yang dikeluarkan sebanding dengan harga yang diterima [2]. Metode fermentasi basah ini dilakukan dengan merendam biji kopi dalam pelarut yang ditambahkan sumber enzim yang bersifat proteolitik (dapat mengurai senyawa protein). Selama proses fermentasi, enzim protease mengurai lapisan lendir (mucilage) yang mengandung protopektin dan gula pada kulit kopi. Penguraian inilah yang diharapkan dapat mengubah cita rasakopi.

Beberapa jenis enzim yang dapat digunakan untuk fermentasi biji kopi diantaranya enzim klorogenat esterase yang diperoleh dari Aspergilus niger dan Lactobacillus johnsonii dan enzim hog liver esterase (HLE) yang diperoleh dari hasil ekstraksi hati babi [3]. Namun penggunaan enzim HLE bertentangan dengan UU Indonesia terkait Jaminan Produk Halal. Enzim yang digunakan pada penelitian ini berasal dari tumbuhan karena kemudahannya untuk diperoleh dan memenuhi undang-undang Indonesia terkait jaminan produk halal. Enzim dapat diperoleh secara alami pada nanas, jahe, kiwi, getah pepaya dan lain-lain [4]. Enzim yang dipilih adalah bromelain dari nanas dan zingibain dari jahe.

Banyak varietas nanas yang termasuk dalam family bromeliaseae mengandung enzim proteolitik yang disebut bromelain [5]. Sekitar setengah dari protein dalam nanas mengandung enzim protease ini. Diantara berbagai jenis buah, nanas merupakan sumber protease dengan rasio tinggi dalam buah yang masak. Selain itu pada buah nanas yang masak memiliki aktivasi yang lebih tinggi dari yang belum masak 
[6]. Enzim bromelain tersebut termasuk ke dalam golongan sufrihidil yang mengandung enzim proteolitik. Selain itu juga mengandung peroksida, asam fosfat, beberapa protease inhibitor, dan organik yang mengikat kalsium. Enzim bromelain menghidrolisis protein yang mengandung ikatan peptida menjadi asam amino yang lebih sederhana. Dalam hal ini sistein endopeptidase secara khusus memotong ikatan peptida pada gugus karbonil seperti yang ditemukan dalam ariginin atau asam amino aromatik yaitu fenilalanin atau tirosin [7].

Secara umum jahe mengandung pati, minyak atsiri, serat, sejumlah kecil protein, vitamin, mineral dan enzim proteolitik [8]. Jahe merupakan sumber protease yang memiliki rendemen 2,3\% atau 176 kali lebih banyak dari pada enzim papain yang memiliki rendemen lebih rendah yaitu $0.013 \%$. Jahe segar mengandung 2,26\% enzim protease. Enzim zingibain termasuk dalam golongan thiol proteinase yang mempunyai gugus sulfihidril bebas. Aktivitas enzim zingibain berkisar antara $0,032 \mathrm{mg}$ peptide/menit $/ \mathrm{mg}$ protein enzim. $\mathrm{pH}$ optimum aktivitas enzim zingibain adalah rentang $\mathrm{pH}$ 4,5-6,0 [9]. Enzim zingibain tersebut dapat memecah ikatan peptida menjadi molekul-molekul protein yang lebih sederhana (asam amino). Hasil pemecahan protein tersebut akan membentuk ikatan yang mengkaitkan dua molekul asam amino yang disebut dipeptida. Dipeptida mempunyai gugus $-\mathrm{COOH}$ dan $-\mathrm{NH}_{2}$ yang akan membentuk oligopeptida seperti carnosine, balenine dan anserine yang memiliki kemampuan sebagai antioksidan. Pemanfaatan zingibain sendiri masih terbatas untuk melunakkan daging [10].

\section{Metode Penelitian}

\section{Pembuatan Kopi Fermentasi}

Biji kopi robusta yang diperoleh dari Desa Mareu, Kecamatan Lamno, Kabupaten Aceh Jaya dipilih yang berwarna merah dan direndam dalam air. Kemudian biji kopi yang tenggelam diambil untuk pengupasan kulit luar kopi (pulping). Selanjutnya biji kopi difermentasikan dengan jahe (sumber zingibain) dan nanas (sumber bromelain) dengan rasio berat sumber enzim banding kopi 1:4 dan 3:4 serta ditambahkan air $100 \mathrm{ml}$. Fermentasi dilakukan selama 1, 2, dan 3 hari pada masing-masing variabel serta digunakan variabel kontrol (tanpa penambahan sumber enzim) dan kopi komersial sebagai pembanding. Setelah fermentasi biji kopi dikeringkan hingga kadar air 12\% untuk pengupasan kulit tanduk (hulling) dan disortir untuk memisahkan biji kopi yang hancur. Tahap terakhir adalah penyangraian (roasting) dan penggilingan (grinding) yang dilakukan dengan mesin. Tahap ini menghasilkan bubuk kopi yang akan diuji fisika, kimia, dan organoleptik.

\section{Pengujian Fisika dan Kimia Kopi}

Pengujian fisika dan kimia kopi terdiri dari kadar air, kadar abu, kadar kealkalian abu, kadar sari kopi, dan kadar kafein. Uji fisika dan kimia kopi didasarkan pada SNI 01-3542-2004. Prosedur pengujian kadar air, kadar abu, dan kealkalian abu mengacu pada SNI 01-2891-1992, sedangkan kadar sari kopi mengacu pada SNI 01-3542-2004. Analisa kadar kafein dilakukan dengan alat High Perfomance Liquid Chromatography (HPLC) Shimadzu LC 20 AD. Prosedur penentuan kadar kafein merujuk pada SNI 01 3542-2004. Kadar kafein sampel diperoleh dengan membandingkan kromatografi standar dan kromatografi sampel yang diuji.

\section{Pengujian Organoleptik}

Uji organoleptik meliputi warna, rasa, dan aroma kopi. Uji ini melibatkan 30 responden yang akan mencoba berbagai sampel kopi. Selanjutnya responden diminta untuk menjawab beberapa pertanyaan yang diajukan dengan skala 1-5.

\section{Hasil dan Pembahasan Pengujian Fisika dan Kimia Kopi}

Gambar 1 menunjukkan pengujian kadar air terhadap berbagai enzim memiliki hasil yang berbeda. Penambahan nanas relatif lebih tinggi dari pada penambahan jahe. Hal ini disebabkan dalam buah nanas memiliki kandungan air mencapai 90\% sedangkan jahe 86\% [11]. Saat proses fermentasi berlangsung kandungan air dalam enzim akan larut dalam biji kopi sehingga semakin tinggi kadar air dalam enzim maka akan berpengaruh terhadap kandungan air pada kopi. Kandungan air yang tinggi menyebabkan mudahnya kopi ditumbuhi oleh jamur sehingga berkurangnya kualitas dan umur simpan kopi [12]. SNI menetapkan batas maksimal kandungan air kopi bubuk adalah 7\%, pada penelitian sebagian sampel belum memenuhi kriteria yaitu pada rasio nanas 1:4 1 hari dan rasio nanas 3:4, 2 dan 3 hari.

Hasil pengujian kadar abu pada Gambar 2 menunjukkan sampel kopi komersial merupakan yang tertinggi dengan persentase $5,66 \%$, sedangkan pada penambahan enzim tidak menunjukkan perbedaan persentase yang tinggi terhadap konsentrasi namun penambahan nanas cenderung lebih tinggi dari pada penambahan jahe. Tingginya persentase kadar abu disebabkan kurangnya kebersihan pada saat proses 
pembuatan dan masih bersisanya kulit yang ari yang terkandung dalam kopi [13], namun disisi lain kopi juga memiliki kandungan mineral dan kadar ini berbeda pada setiap varietasnya tergantung pada letak ketinggian penanaman kopi [2]. SNI menetapkan batas maksimal kadar abu yang diperbolehkan dalam kopi bubuk adalah $5 \%$.

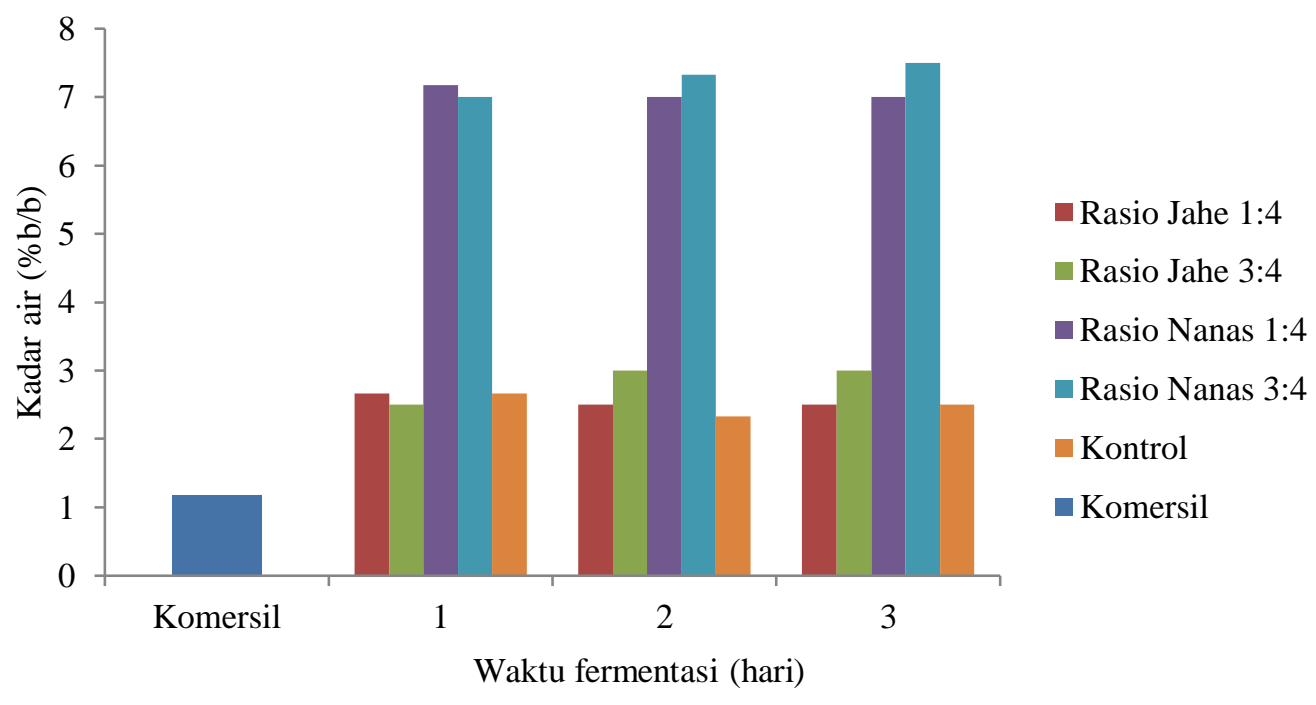

Gambar 1. Persentase kadar air kopi bubuk pada berbagai perlakuan

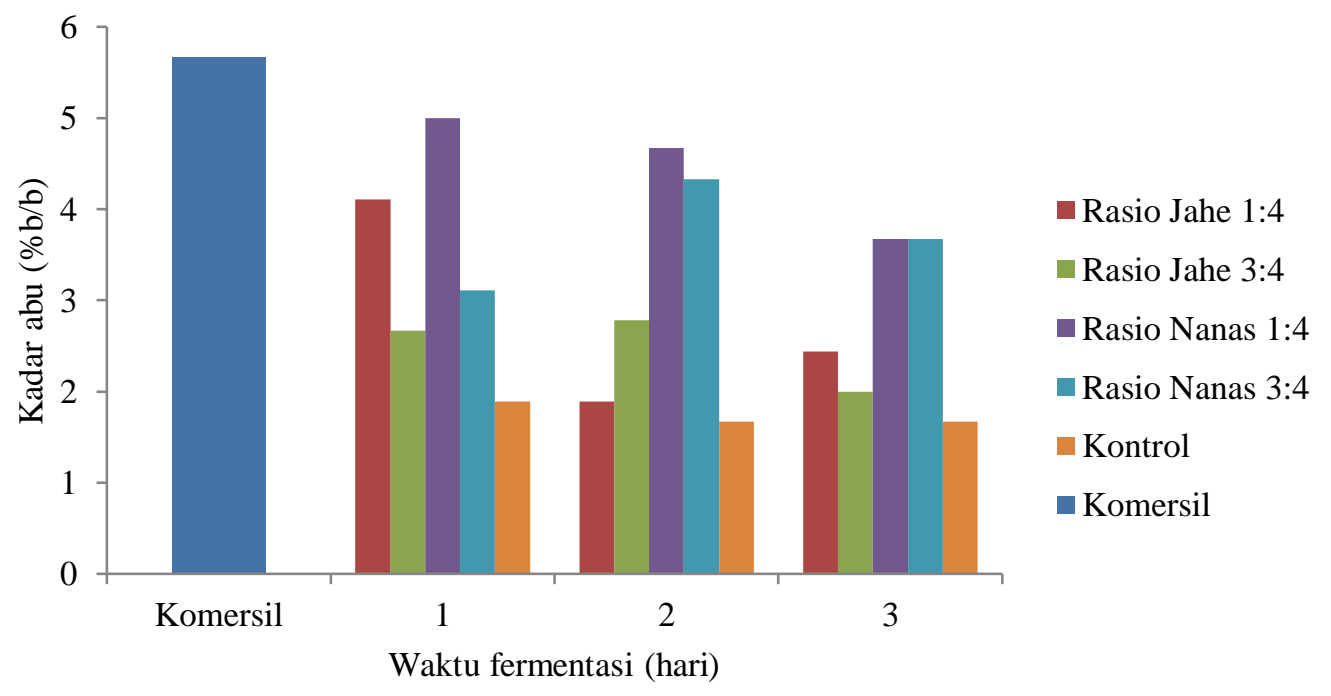

Gambar 2. Persentase kadar abu kopi bubuk pada berbagai perlakuan

Kadar sari kopi merupakan indikator yang menunjukkan seberapa banyak zat yang dapat larut dalam air selama penyeduhan kopi. Penambahan konsentrasi enzim tidak berpengaruh terhadap kadar sari kopi yang diperoleh, akan tetapi faktor yang mempengaruhi nilai kadar sari kopi adalah kelarutan. Faktor yang mempengaruh kelarutan pada kopi yaitu suhu, waktu dan luas permukaan bubuk kopi [14]. Persentase kadar sari kopi yang diperoleh pada penelitian ini telah memenuhi persentase SNI dengan syarat maksimal 60\%. Gambar 3 menunjukkan kadar sari kopi pada berbagai perlakuan.

Gambar 4 menunjukkan hasil kadar kealkalian abu pada penambahan jahe lebih tinggi dari nanas. Hasil penelitian sebelumnya menyatakan bahwa tingginya persentase kadar kealkalian abu dengan penambahan enzim disebabkan oleh tingginya kandungan abu pada sumber enzim yaitu jahe dan nanas [14]. Jahe mengandung abu sebanyak 6,63\% per 100 gram [15] dan nanas sebanyak 0,45\% [16]. Abu yang diperoleh dari hasil pengabuan kopi bersifat alkalis, hal ini disebabkan sebagian dari komponen penyusunnya terdiri dari senyawa fosfat dan natrium karbonat. Berdasarkan hasil penelitian yang telah dilakukan kadar kealkalian abu pada kopi sudah memenuhi SNI yaitu minimal $35 \mathrm{ml}$ x N. NaOH/100g. 


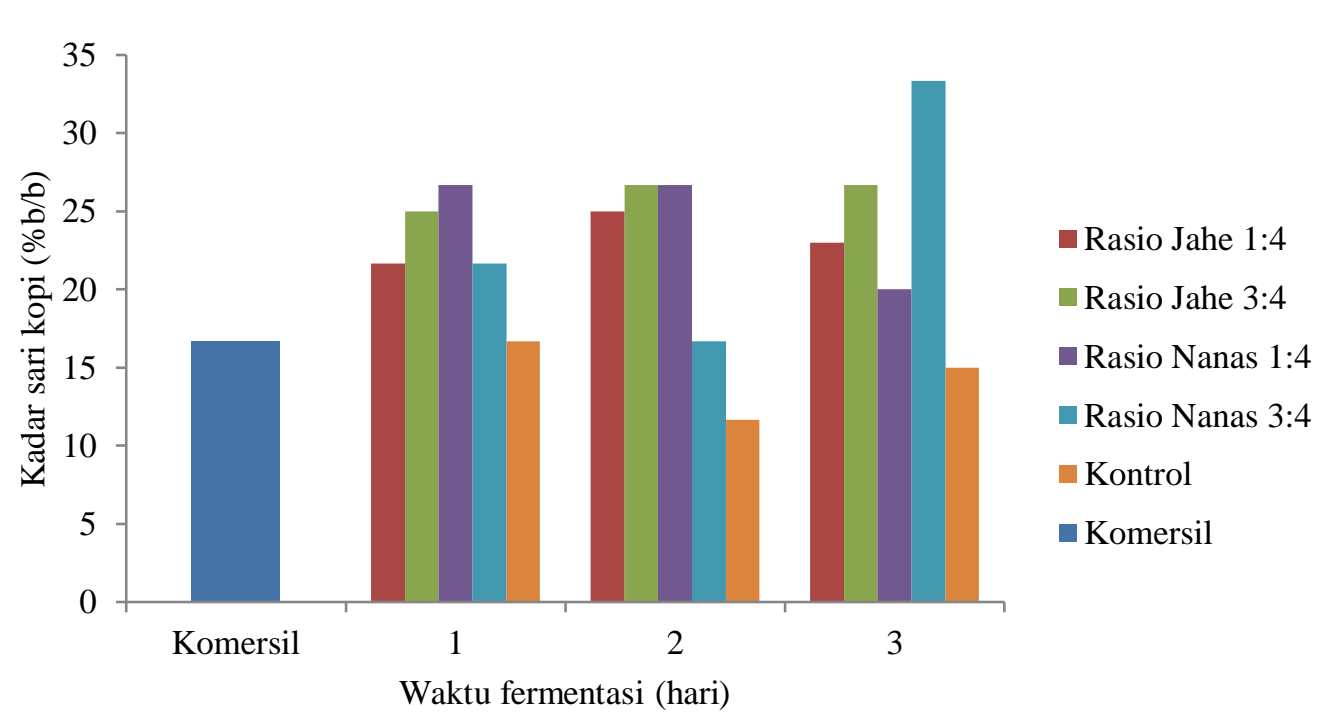

Gambar 3. Persentase kadar sari kopi kopi bubuk pada berbagai perlakuan

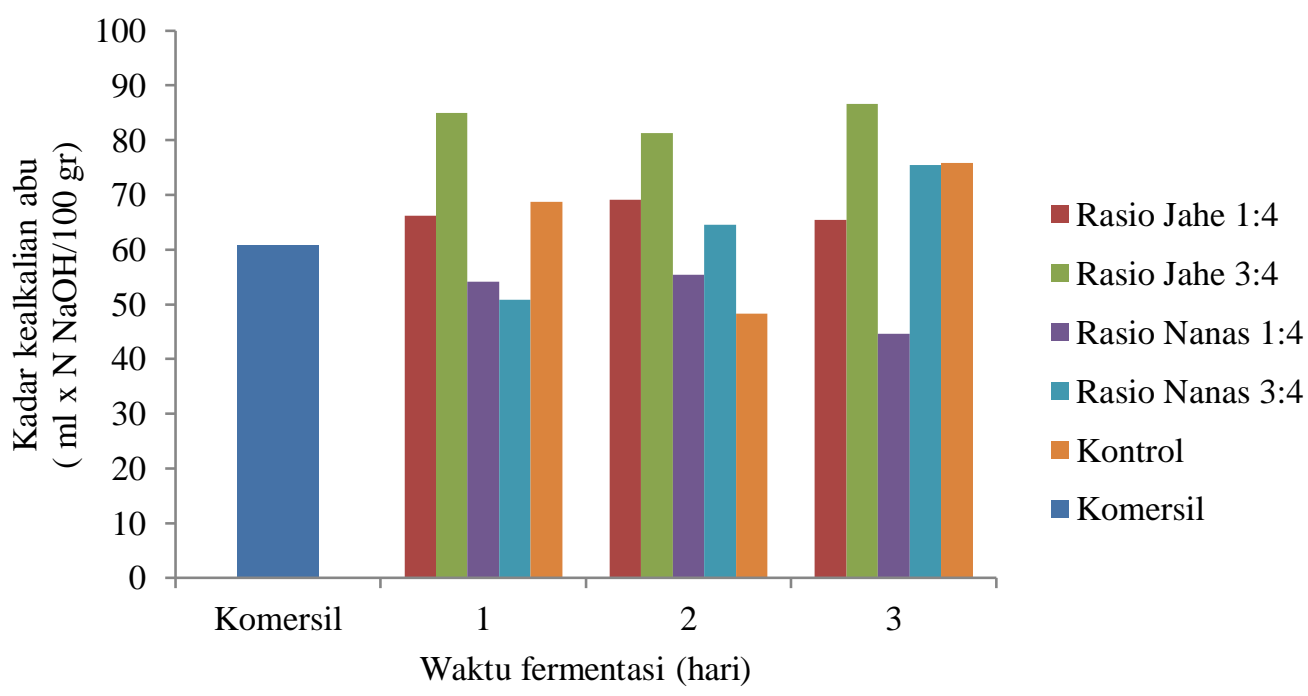

Gambar 4. Persentase kadar kealkalian abu kopi bubuk pada berbagai perlakuan

Hasil analisa kadar kafein pada Gambar 5 menunjukkan adanya penurunan kadar kafein terhadap perbedaan jenis sumber enzim yang digunakan. Penurunan kadar kafein juga terjadi pada perbedaan lama waktu fermentasi baik pada kopi yang ditambahkan sumber enzim maupun yang tidak ada sumber enzim (kontrol). Hal ini disebabkan kandungan pada sumber enzim memiliki sifat proteolitik yang mampu menghancurkan sejenis protein dan menghambat pembentukan gel untuk gelatin, sedangkan kafein memiliki sifat yang mirip dengan protein. Perbedaan dari jenis sumber enzim yang digunakan juga mempengaruhi terhadap tingkat penurunan kafein, penggunaan nanas memiliki tingkat degradasi kafein yang lebih tinggi dari pada penggunaan jahe dan kontrol.

Hal ini disebabkan dalam buah nanas mengandung enzim bromelin aktif sebanyak 15,33 unit/gr, sedangkan jahe mengandung 2,26\% enzim zingibain [4]. Berdasarkan perolehan persentase kadar kafein kopi bubuk yang telah dilakukan kadar kafein pada kopi fermentasi telah memenuhi SNI yang menyatakan kadar kafein yang dibolehkan pada kopi kurang dari $2 \%$ sedangkan pada bubuk kopi komersial tidak memenuhi SNI dengan kadar kafein 2,11\%.

\section{Pengujian Organoleptik}

Menentukan kopi yang terbaik selain dilakukan analisa fisika dan kimia pada kopi namun juga diuji organoleptik. Jenis pengujian pada penelitian adalah pengujian hedonik. Uji hedonik bertujuan untuk mengetahui tingkat kesukaan panelis yang meliputi warna, aroma dan rasa dengan skala 1 sampai 5 . 
Pengujian organoleptik ini dilakukan oleh 30 panelis semi terlatih dari mahasiswa Jurusan Teknologi Hasil Pertanian Fakultas Pertanian Universitas Syiah Kuala.

Gambar 6 menunjukkan kopi dengan rasio nanas 3:4 dengan waktu fermentasi 3 hari merupakan warna kopi yang disukai oleh panelis dengan nilai rata-rata 3,3. Sedangkan kopi selanjutnya warna yang disukai oleh panelis dengan rasio jahe 1:4 waktu fermentasi 1 hari yaitu 3,27 serta komersial yaitu 3,20. Namun dari setiap nilai rata-rata yang diperoleh tidak menunjukkan perbedaan yang nyata terhadap berbagai perlakuan seperti pada perlakuan kontrol dengan fermentasi 1,2 dan 3 hari diperoleh nilai rata-rata kesukaan warna adalah 3,03, 3,06 dan 2,9, sedangkan pada perlakuan rasio jahe 3:4 diperoleh pada hari fermentasi 1, 2 dan 3 adalah 3,03, 3 dan 2,96.

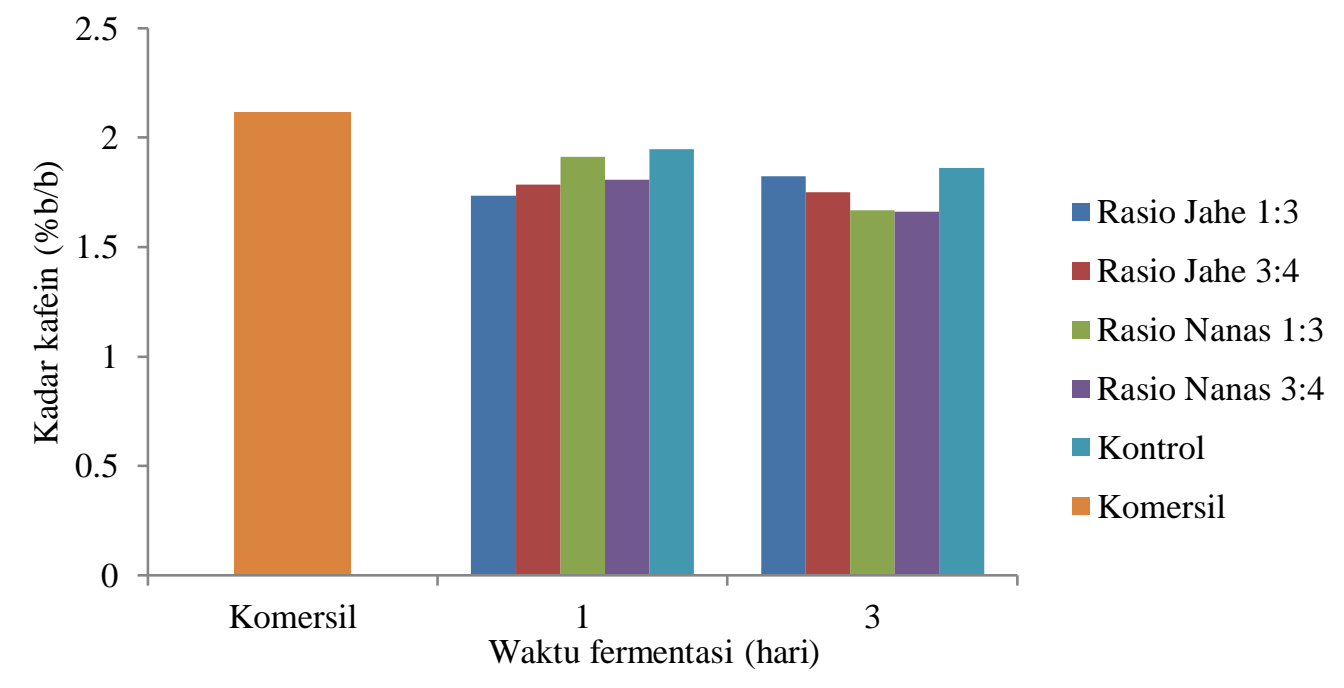

Gambar 5. Persentase kadar kafein kopi bubuk pada berbagai perlakuan

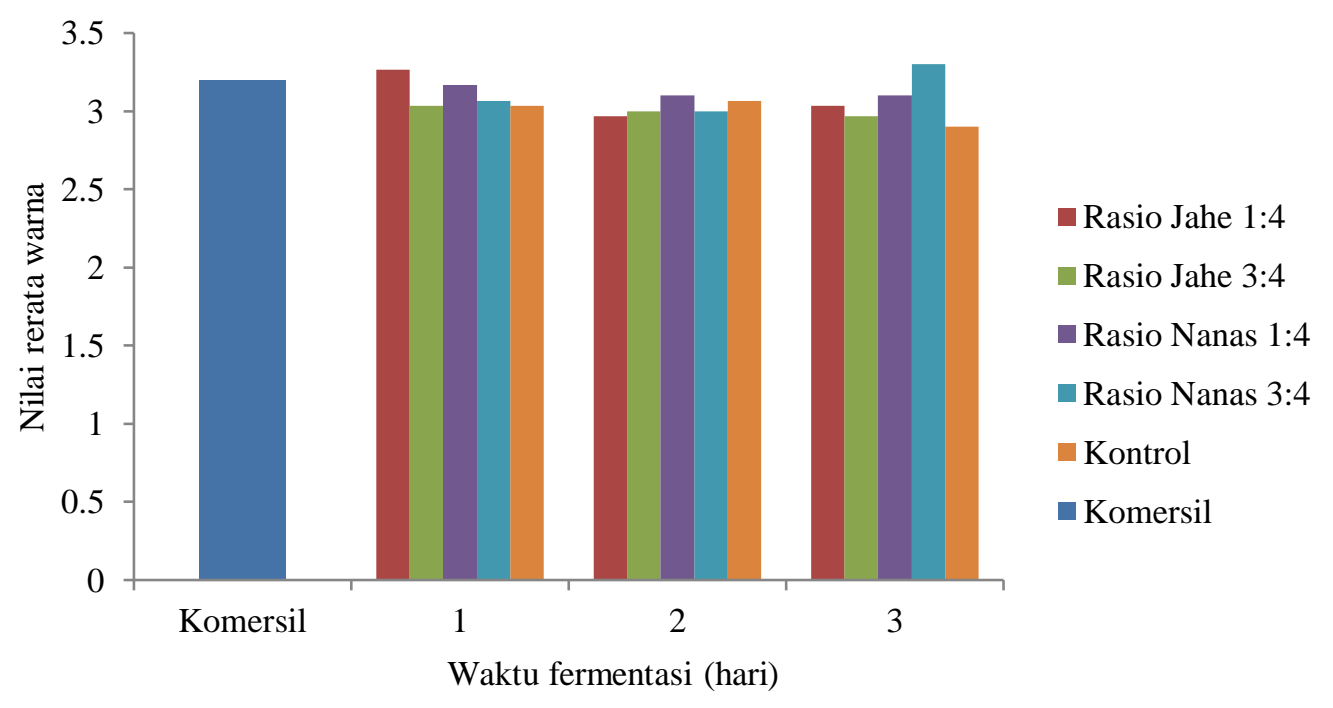

Gambar 6. Nilai rata-rata uji kesukaan warna kopi

Perubahan warna disebabkan karena terbentuknya reaksi maillard pada kopi yang melibatkan senyawa gugus karbonil (gula reduksi) dan gugus amino (asam amino) [17]. Adanya penambahan enzim pada fermentasi kopi mengakibatkan terjadinya hidrolisis protein menjadi asam amino bebas sehingga semakin meningkatnya asam amino bebas dan gula perduksi maka akan mempercepat terjadinya reaksi maillard yang menyebabkan perubahan warna pada biji kopi semakin gelap. Perubahan suhu roasting tidak menunjukkan perbedaan yang nyata terhadap perubahan warna kopi, namun lamanya roasting sangat berpengaruh terhadap warna kopi [18]. 
Penilaian aroma pada Gambar 7 menunjukkan kopi dengan rasio jahe 1:4 merupakan aroma yang disukai oleh panelis dengan nilai rata-rata 3,27, selanjutnya aroma yang disukai oleh panelis adalah kopi komersial dengan nilai rata-rata 3,23. Sama halnya dengan perolehan nilai rata-rata terhadap kesukaan warna, nilai kesukaan aroma juga tidak menunjukkan perbedaan yang nyata terhadap kesukaan panelis akan berbagai perlakuan fermentasi kopi. Aroma khas pada kopi disebabkan karena adanya pembentukan senyawa yang dihasilkan dari golongan asam amino seperti leusin, iso leusin, varline, alanine, theorinin, glisin dan asam aspartat. Terjadinya perubahan aroma pada kopi disebabkan oleh adanya aktivitas enzim proteolitik yang menghidrolisis kandungan protein sehingga meningkatnya asam amino bebas pada kopi [17].

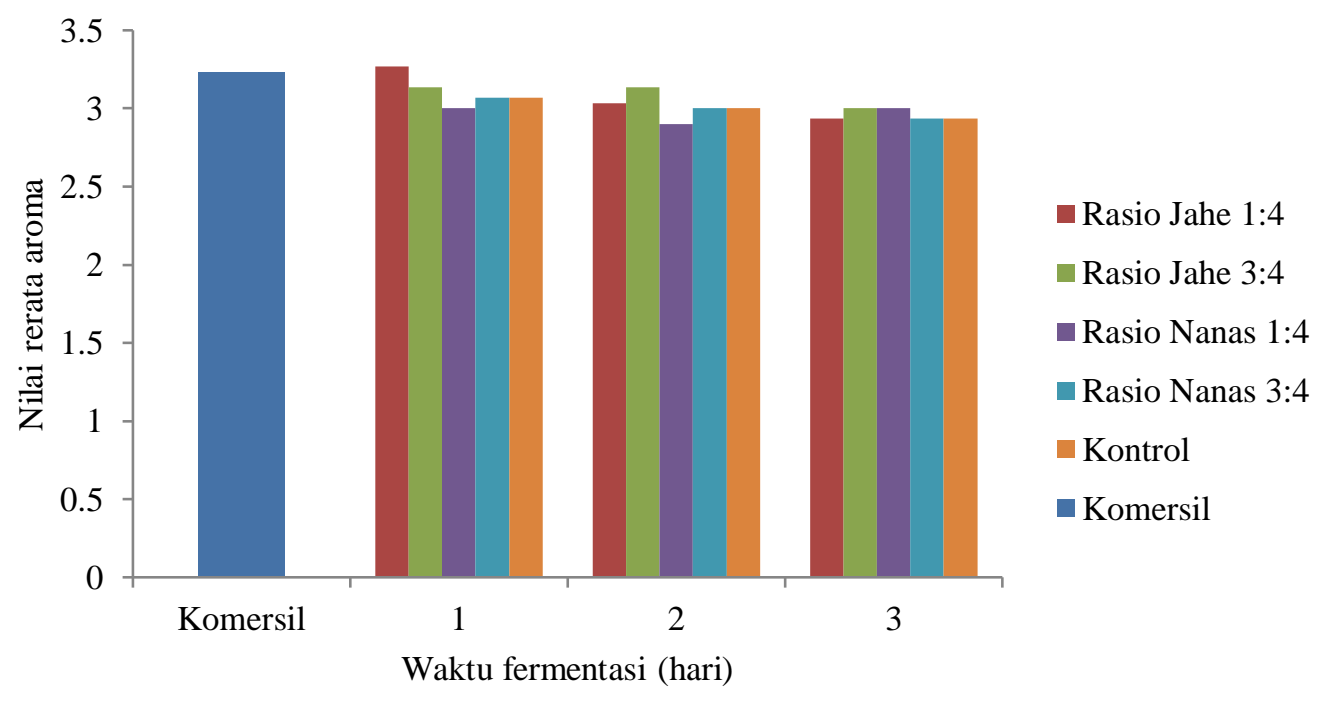

Gambar 7. Nilai rata-rata uji kesukaan aroma kopi

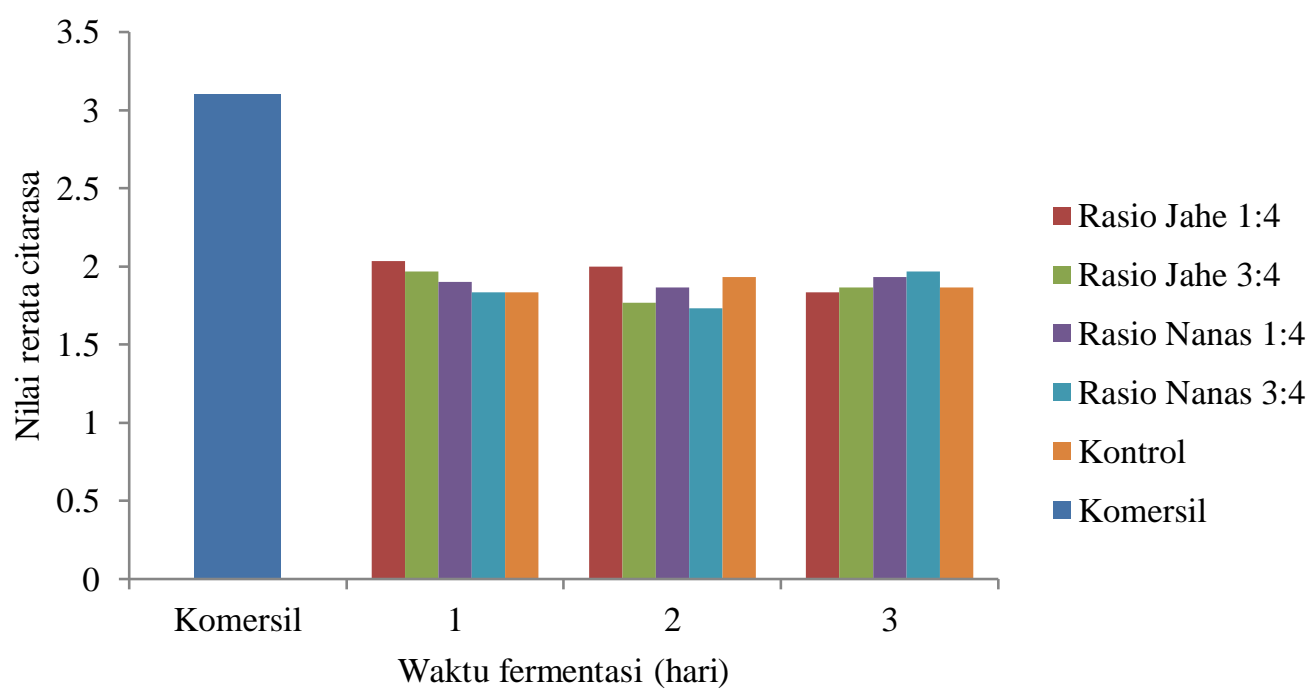

Gambar 8. Nilai rata-rata uji kesukaan aroma kopi

Nilai dari uji cita rasa pada Gambar 8 menyatakan bahwa kopi komersial merupakan kopi yang disukai oleh panelis dengan nilai rata-rata 3,10. Sedangkan kopi perlakuan yang disukai oleh panelis adalah pada rasio jahe 1:4 dengan waktu fermentasi 1 hari yaitu 2,03. Sampel yang lain tidak menunjukkan pengaruh yang spesifik terhadap perolehan nilai cita rasa kopi dengan berbagai perlakuan. Pengaruh penambahan enzim selama proses fermentasi pada biji kopi menyebabkan terjadinya pengurangan kadar kafein yang dimana berperan sebagai penyumbang rasa pahit pada kopi bubuk. Hal ini disebabkan terjadinya hidrolisis protein menjadi asam amino bebas, sedangkan kafein memiliki sifat yang mirip dengan 
protein yaitu memiliki gugus amida [4]. Pada saat proses fermentasi, enzim protease akan mendegradasi lapisan mucilage pada permukaan kopi hingga ke sitoplasma yang mengandung kafein dalam keadaan bebas [19].

Selain dari proses fermentasi, degradasi senyawa juga terjadi pada proses penyangraian yang menyebabkan terjadinya perubahan rasa pada kopi bubuk, beberapa senyawa yang terdegradasi diantaranya karbohidrat, alkaloid, asam klorogenat, senyawa volatil dan trigonelin. Selama proses penyangraian, karbohidrat terdegradasi membentuk sukrosa dan gula-gula sederhana, sedangkan asam klorogenat akan terdekomposisi sebanyak 50\% dan akan hilang pada suhu tinggi serta trigonelin hanya 15\% yang terdekomposisi. Senyawa alkaloid yaitu kafein akan mengalami sublimasi membentuk kafeol dan memberikan kontribusi terhadap cita rasa pahit pada kopi sebesar 10\%. Sehingga apabila kopi terlalu lama disangrai pada suhu tinggi akan menyebabkan hilangnya semua cita rasa pada kopi [18].

\section{Kesimpulan}

Berdasarkan penelitian yang telah dilakukan penambahan enzim protease selama fermentasi kopi dapat memperbaiki mutu kualitas kopi mengacu pada SNI-01-3542-2004. Hal ini dapat ditinjau dari aspek fisika-kimia dan aspek organoleptik yang diuji. Pengujian organoleptik menunjukkan fermentasi dengan nanas pada rasio 3:4 selama 3 hari dapat meningkatkan kesukaan pada warna kopi dan fermentasi dengan jahe pada rasio 1:4 selama 1 hari dapat meningkatkan kesukaan pada aroma kopi.

\section{Referensi}

[1] Kraehenbuehl, K., Page-Zoerkler, N., Mauroux, O., Gartenmann, K., Blank, I., Bel-Rhlid, R. 2017. Selective enzymatic hydrolysis of chlorogenic acid lactones in a model system and in a coffee extract. Application to reduction of coffee bitterness. Food Chemistry, 218: 9-14.

[2] Afriliana, A. 2018. Teknologi Pengolahan Kopi Terkini. Yogyakarta: Deep Publish.

[3] Ardiansyah, D., Tjota, H., Kiyat, W. El. 2018. Review: Peran Enzim Dalam Meningkatkan Kualitas Kopi. Jurnal Agri-Tek: Jurnal Penelitian Ilmu-Ilmu Eksakta, 19(2).

[4] Oktadina, F. D., Argo, B. D., Hermanto, M. B. 2013. Pemanfaatan Nanas (Ananas Comosus L . Merr) untuk Penurunan Kadar Kafein dan Perbaikan Cita rasa Kopi (Coffea Sp) dalam Pembuatan Kopi Bubuk. Keteknikan Pertanian Tropis Dan Biosistem, 1(3): 265-273.

[5] Silaban, I., Rahmanisa, S. 2016. Pengaruh Enzim Bromelin Buah Nanas (Ananas Comosus L.) Terhadap Awal Kehamilan. Majority, 5(4): 80-85.

[6] Purwaningsih, I. 2017. Potensi Enzim Bromelin Sari Buah Nanas (Ananas Comosus L.) Dalam Meningkatkan Kadar Protein Pada Tahu. Jurnal Teknologi Laboratorium, 6(1): 39.

[7] Masri, M. 2014. Isolasi Dan Pengukuran Aktivitas Enzim Bromelin Dari Ekstrak Kasar Bonggol Nanas (Ananas Comosus) Pada Variasi Suhu Dan pH. Biogenesis, 2(2): 119-125.

[8] Kusnadi, N. D., Sukohar, A., Carolia, N., dan Setiawan, G. 2013. Pengaruh Pemberian Ekstrak Jahe Merah (Zingeber Officinale Var Rubrum) Terhadap Penurunan Kadar Asam Urat Darah Obesitas The Effect Of Ginger Red Extract (Zingiber Officinale Var Rubrum) On The Decrease In Acid Uric Content Blood Of Obesity, 7(1).

[9] Fuad, M. 2012. Analisis Jenis Dan Konsentrasi Enzim Terhadap Daya Simpan VCO (Virgin Coconut Oil). Agrointek, 6(2): 112-117.

[10] Fadhila, R., Darmawati, S. 2017. Profil Protein Daging Kambing, Kerbau Dan Sapi Yang Direndam Larutan Jahe Berbasis Sds-Page. Prosiding Seminar Nasional dan Internasional. 25-33.

[11] Hartati, M. E. 2013. Pengaruh Penambahan Pati Jahe Hasil Samping Pembuatan Jahe Instan Pada Mutu Kue Kering. Baristand Industri Surabaya, 24-31.

[12] Mufti, M., Lutfi, M., Halim, N., Arifan, I. S., Studi, P., Mesin, T., Teknik, F. 2018. Analisa Pengaruh Variasi Putaran Dan Temperatur Drum Terhadap Hasil Pengeringan Kopi Pada Type Drum Dryer. Mekanika - Jurnal Teknik Mesin, 4(1).

[13] Palungan, M. B., Rapa, C. I., Salu, S. 2018. Process Of Coffee Processing Of Arabic Powder And Physical Changes Due To Adjustment Temperature. Kupang. In Prosiding SNTTM. 268-271.

[14] Achadiyah, S. 2007. Kajian Pembuatan Kopi Jahe Celup (Study Of Ginger Coffee Bag Preparation). Agroteknose, 3(2): 1-6.

[15] Ugwoke, C., Nzekwe, U. 2010. Phytocvhemistry and proximate composition of ginger (Zingiber Officinale). Journal of Pharmaceutical and Allied Sciences, 7(5): 1182-1187.

[16] Izundu, A. I., Chukwuma, M. O., Esther, A. E., Adimonyemma, R. N., Iroka, C. F. 2016. Effects of Induced Ripening Methods on the Proximate, Biochemical and Mineral Compositions of Ananas Comosus (Pineapple Fruit). International Journal of Research in Pharmacy and Pharmaceutical 
Sciences, 1(1): 16-22.

[17] Daisa, J., Rossi, E., Dini, I. R. 2017. Pemanfaatan Ekstrak Kasar Enzim Papain pada Proses Dekafeinasi Kopi Robusta. Jom Faperta, 4(1): 1-14.

[18] Purnamayanti, N. P. A., Gunandya, I. B. P., Gede, A. 2017. Program Studi Teknik Pertanian, Fakultas Teknologi Pertanian Unud. Jurnal Beta (Biosistem Dan Teknik Pertanian), 5(2): 39-48.

[19] Noviar, D., Ardiningsih, P., Alimuddin, A. H. 2016. Pengaruh Ekstrak Kulit Buah Nanas (Ananas Comosus L. Merr) Terhadap Karakteristik Fisika Kimia Dan Cita Rasa Kopi (Coffea sp). Jurnal Kajian Komunikasi, 5(4): 40-46. 